IJMS 27(1), 49-72 (2020)

How to cite this article:

Ab. Hamid, S. N., Wan Jusoh, W. J., \& Maulan, S. (2020). Corporate brand image of Islamic bank in Malaysia: Antecedents and consequence. International Journal of Management Studies, 27(1), 49-72. https://doi.org/10.32890/ ijms.27.1.2020.7524

\title{
CORPORATE BRAND IMAGE OF ISLAMIC BANK IN MALAYSIA: ANTECEDENTS AND CONSEQUENCE
}

\author{
*SITI NGAYESAH AB HAMID \\ Faculty of Economics and Management \\ Universiti Kebangsaan Malaysia \\ WAN JAMALIAH WAN JUSOH \\ SUHARNI MAULAN \\ Kulliyyah of Economics and Management Sciences \\ International Islamic University Malaysia \\ *Corresponding author: ctngayesah@ukm.edu.my
}

\begin{abstract}
The role of corporate brand image in influencing the survival of companies has never been underestimated. Because of this, this study intends to examine the antecedents and the consequence of corporate brand image towards customer behaviour. A model proposing firms and non-firms communication as the antecedents and loyalty as the consequence was proposed. One hundred and sixty-eight (168) questionnaires were collected and data was analysed based on the Partial Least SquareStructural Equation Modeling (PLS-SEM). The result of the study revealed that both firm and non-firm communication play a significant role in shaping the corporate brand image of an Islamic bank, especially in Malaysia. Corporate brand image on the other hand was also found to influence customers' loyalty. These findings have broadened the understanding of the corporate brand image's antecedents and the consequence also shows the importance of managing the Islamic bank corporate communication.
\end{abstract}


IJMS 27(1), 49-72 (2020)

Keywords: Corporate brand image, corporate communication, Islamic bank, loyalty.

Received: 13/12/2019 Revised: 11/06/2020 Accepted: 15/06/2020 Published: 23/07/2020

\section{Introduction}

The Islamic financial sector has shown encouraging growth over the past few decades. Started from a small bank in a remote area of Egypt, the Islamic banking concept has spread throughout the world, reaching a value of USD2.19 trillion globally as in the second quarter of the year 2018 (IFSB, 2019) . However, despite this encouraging success, Islamic bank has been viewed as less popular and less experienced as compared to the conventional banks (Suhartanto, 2019). Not only that, studies also have shown that there are still consumers who are unaware of the differences between the concept of an Islamic bank as compared to its conventional counterparts (AlTamimi, Lafi, \& Uddin, 2009; Belwal \& Al Maqbali, 2019; Kaakeh, Hassan, \& van Hemmen Almazor, 2018; Souiden \& Rani, 2015). This is applicable not only among Muslim customers, but also among non-Muslim target markets, as Mohamad and Majid (2016) claimed that non-Muslim customers are aware of the Islamic bank but have low knowledge and understanding on the concept. In addition, the Islamic banking institutions also have been accused to only be a mere depiction of the conventional bank, with the only exception on the Arabic terms used (Khan, 2010). The shari'ah compliance aspect has been questioned (Belwal \& Al Maqbali, 2019; Chong \& Liu, 2009; Khan, 2010), indicating the bank weakness in communicating its differences and building a desirable image. All of these including the aggressive competition in a dual banking market in which Islamic and conventional banks are operating side by side leads to a decline in customer loyalty (Saleh, Quazi, Keating, \& Gaur, 2017), which may then affects the bank revenue.

Therefore, in facing these challenges, the Islamic banking institution is proposed to focus on branding effort by developing a strong corporate brand image (Ahmad, Rustam, \& Dent, 2011; Chaouch, 2017) through effective communication (Chaouch, 2017; Haniffa \& Hudaib, 2007). Previously, studies on the corporate brand image of Islamic bank have mainly focused on the emotional aspect of the brand only (Ahmed, Ali, Jan, \& Hassan, 2019; Osman, Ali, Mokhtar, Setapa, \& Abd Malek, 
2016; Osman et al., 2015). While the image is said to be influenced by various factors, in general, corporate brand image is generated by what people say about the institutions and what the institutions say about themselves (Dowling, 1993). In view of these, communication is therefore believed to be crucial in influencing the image building process (Palazzo, Foroudi, Kitchen, \& Siano, 2020). However, despite the importance of understanding this communication aspect, studies available so far have focused more on the sender sides compared to the receivers' perspective (Cornelissen, 2000). Not only that, existing literature so far has rarely tried to understand the role of communication in the formation of image (Tran, Nguyen, Melewar, \& Bodoh, 2015). To make it worse, the few available studies on the communication and image relationship also have found contradicting result with some studies have indicated the existence of significant relationship between corporate communication and image (Bravo, Montaner, \& Pina, 2012), while other studies unable to prove the same (Ab Hamid \& Wan Jusoh, 2016). In addition, despite findings in the conventional banking context that image is an important driver of customer behaviour, few studies have investigated this factor in the Islamic banking context (Suhartanto, 2019).

Hence, triggered by the above issues, in general, this study intends to investigate the relationship between corporate communication as a factor that influences the corporate brand image of Islamic bank and its consequence, which is loyalty. The findings of this study would provide marketers with the knowledge to prioritise its communication efforts in designing the desirable corporate brand image, thus influencing customer loyalty.

The following sections of this paper are structured as follows: First, the literature related to the corporate brand image is presented; second, the hypotheses undermining the study are explained; third, the research methodology and data analysis are elaborated, and finally, the paper is concluded with discussions of the findings and their implications, including suggestions for future research.

\section{Literature Review}

Image is a complex concept that has been described by different authors in different ways (de Chernatony \& Riley, 1998). In the simplest term, an image can be explained as a 'total impression an entity makes on the mind of others' (Dichter, 1985; Dowling, 1993). 
Elaborately, image is defined by Aaker, Batra, and Myers (1982) 'as the set of meanings by which an object is known and through which people describe, remember and relate to it. That is, it is the net result of the interaction of a person's beliefs, ideas, feelings and impressions about an object' in which the object according to Dowling (1986) could be replaced with a brand, company, product, etc. Corporate image on the other hand is defined by Johnson and Zinkhan (1990) as an overall impression towards a company or an institution held by its various stakeholders. Corporate brand image, which is similar to corporate image (Blombäck \& Axelsson, 2007), therefore could simply be understood as the interaction of stakeholders' beliefs, feelings, impressions, and ideas that resulted in a mental picture of an institution or organisation.

Scholars argued that image is an important aspect of a powerful brand (Hosany, Ekinci, \& Uysal, 2006) and plays a crucial role in the development of brand equity (Ansary \& Nik Hashim, 2018; Shabbir, Khan, \& Khan, 2017). In a competitive market, creating an image is said to be part of a positioning strategy (Kuuru \& Tuominen, 2016) to differentiate an offering or a company from competitors (Bălășescu, 2019). In the case of intangible service, or a parity product, image is used to define a product in consumers' minds, and able to influence selection and intention to purchase (Michaelidou, Micevski, \& Cadogan, 2015). Evidence showed that image is a strong purchase influencer (Widyastutir \& Said, 2017) and the first determinant used in selecting a service (Hee Youn \& Ji-Hwan, 2013; Hung, 2008; Nguyen et al., 2016).

In addition, image also has been found to have an impact on perceived quality (Konuk, 2018), satisfaction (Lahap, Ramli, Radzi, Said, \& Zain, 2016; Sallam, 2016) and loyalty (Chung, Yu, Kim, \& Shin, 2016; Farida \& Ardyan, 2018). In general, this is valid especially in the case of Islamic bank in which the services delivered are difficult to be evaluated, and customers are said to be having limited understanding and knowledge on the products offered, which resulted in an image being the most important driver of customer's future behaviour (Prayag, Hosany, Muskat, \& Del Chiappa, 2017).

As such, building a strong image should be a top priority of many businesses ( $\mathrm{O}^{\prime}$ Cass \& Grace, 2003), as it is one of the intangible assets that cannot be copied by competitors (Yeo \& Youssef, 2010). Not only that, in the service's context, the creation of a proper corporate image is more important than the product, especially because of its intangible 
nature (Berndt \& Hollebeek, 2019). Therefore, in order to develop a favourable image, it is essential for companies to understand its current image, as it could be used as a basis to improve its existing position in the mind of customers (Dowling, 1986; Klein, Völckner, Bruno, Sattler, \& Bruno, 2019). Identifying the most important factors that influence image is thus important so that corrective action could be taken and future strategies could be developed (Barich \& Kotler, 1991).

\section{Corporate Communication}

Corporate communication is a strategic concept that could be applied in the management of image and reputation (Palazzo et al., 2020). Basically, Balmer and Gray (2000) defined corporate communication as the accumulation of messages from formal and informal sources, delivered through various media, for the purpose of conveying a company's identity to the stakeholders and multiple audiences. In general, corporate communication definition could be categorised into three areas in which first, its main purpose is to communicate the overall plan of a company; second, to incorporates internal and external communication to develop, maintain or restore an image or reputation of a company; and third, corporate communication concerns on maintaining the relationship with the internal as well as external stakeholders (Mazzei, 2014). Taking these into account, therefore, corporate communication in this study is defined as a process of conveying the company's identity and creating images through an integration of various messages delivered formally and informally via various media targeted not only to the stakeholders but also to multiple audiences.

Several scholars have tried to describe the concept of corporate communication. Initially, Van Riel (1995) proposed that corporate communication could be categorised into three forms named as management communication, organisational communication and marketing communication (Balmer \& Greyser, 2003). While management communication focuses on the internal audiences within the organisation, and organisational communication concerns on the multiple stakeholders such as suppliers, government and the media, marketing communication on the other side aim towards the endusers, intending to create interest and awareness on the organisation products or services through several tools including advertising, sales promotion, public relation and direct mail. On a different side, Balmer and Gray (2000) proposed a Total Corporate Communication 
concept which categorised the company's communication effort into three parts which are primary, secondary and tertiary communication. The primary communication concerns the effects of communication towards the company policy, product or service performance, and behaviour of the employees. On the other hand, secondary communication refers to the planned communication efforts of the company using various communication channels including advertising, public relations and visual identification system. Secondary communication is said to be the reflection of Van Riel's marketing communication with the purpose to reinforce and support the primary communication. Finally, the tertiary communication involves the effects of communication on thirdparty messages which may include word-of-mouth and other forms of communication transmitted by competitors, media interpretation and opinion leaders' commentary. In summary, the three forms of communication proposed by Van Riel and the Balmer and Gray (2000) primary and secondary communication could be categorised as firm's communication while the tertiary communication could be considered as non-firm communication. However, as the setting of this study is focusing specifically on the consumers' perspective only, management communication and organisational communication proposed by Van Riel is therefore irrelevant.

\section{Firm Communication}

A firm communication could be defined as a company's planned and controlled communication strategies directed towards its internal and external stakeholders using various mediums of communication (Bravo et al., 2012). However, as the context of this study is on the consumers, it will focus on the effectiveness of various medium communicating corporate identity only, which in the banking sector is said to include corporate advertising (Bravo et al., 2012; Sadek, Redding, \& Tantawi, 2015), public relation (Gaither \& Al-Kandari, 2014; Sadek et al., 2015), and several marketing promotional tools including personal selling and direct marketing (Sadek et al., 2015). The findings of previous study revealed that these communication aspects directly influence the corporate brand image of banking institutions (Yeo \& Youssef, 2010).

\section{Non-firm Communication}

Non-firm communication refers to the messages about a company or its products and services from other sources that are unable 
to be controlled by the company (Berry, 2000). It usually reaches fewer people than firm communication but is still able to influence consumers' impressions and awareness about a company's brand through a dotted line relationship. However, in extreme cases in which the messages become widely-spread, this dotted line could change to be bold (Berry, 2000). Balmer and Gray (2000) classify non-firm communications under three categories: word-of-mouth, interpretation and spin by the media, also communication from the competitor. Cornelissen (2000) on the other hand divided this type of communication into other communication which refers to the media and competitors communication, interpersonal communication or word-of-mouth also interpersonal communication which refers to the receivers' prior experience and existing knowledge regarding the subject. In general, non-firm communication comes in the form of word-of-mouth and publicity (Berry, 2000).

\section{Loyalty}

The objective of most marketing activities conducted by a company is usually directed towards the establishment, maintenance and improvement of customers' loyalty (Dick \& Basu, 1994). Customer loyalty which resulted in repeat patronage or repeat purchase is said to be among the most important target of service marketing (Juhari, Bhatti, \& Piaralal, 2016). Customers who are loyal would spend more at the company and tend to be less price-sensitive as compared to the other customers (De Leaniz \& Del Bosque Rodríguez, 2016). Loyalty has been defined in various ways by different authors according to the means it is measured. In some study, loyalty is referred to as the attitudinal and behavioural preference to favour one corporation compared to others (Giovanis \& Tsoukatos, 2017), while in another study, loyalty is defined as the psychological process that results in a certain purchase behavioural inclination excluding the repetition of purchase done randomly (Esmaeilpour, 2015). Previous studies suggested that the establishment of customer loyalty could be influenced by corporate image and reputation. However, not many empirical studies available supporting this proposition (De Leaniz \& Del Bosque Rodríguez, 2016).

\section{Hypotheses and Conceptual Framework}

The relationship between corporate communication, corporate brand image and loyalty could be explained among others by the corporate 
image formation process developed by Tran et al. (2015). The formation process started with variables that build corporate communication and corporate personality which then influence the formation of corporate image. A favourable corporate image then will be linked to awareness, familiarity, favourability, trust and advocacy, which signify loyalty. In empirical studies, the link between the two forms of corporate communication which are firm and non-firm communication with corporate brand image has been investigated before. For example, Bravo et al. (2012) specifically prove that firm communication has a significant impact towards the image of conventional financial institutions. In a comparative study, Awan, Hayat, and Faiz (2018) found that firm communication indeed positively related to the image of a conventional bank, but in the context of Islamic banks, the same hypothesis is not supported.

On the other hand, Cornelissen (2000) in its new corporate communication model proposed the existence of non-firm communication influence towards the corporate brand image. This is supported by Bravo et al. (2012) that found a significant relationship between non-firm's communication and the corporate brand image of conventional financial institutions. Awan et al., (2018) on the other hand found a mixed result in which nonfirm communication is significantly related to the corporate brand image of Islamic banks, but has no influence on the image of a conventional bank.

In the aspect of loyalty, many studies have tried to examine the relationship that exists between corporate image and loyalty. In the context of online retailing, Da Silva and Syed Alwi (2008) found that online corporate brand image influence loyalty significantly. This is also supported in the offline setting in which corporate brand image is concluded to have a significant relationship with loyalty (Da Silva \& Syed Alwi, 2006). In the field of colour cosmetics, brand image has also been found to have a significant effect on loyalty (Sondoh Jr, Wan Omar, Abdul Wahid, Ismail \& Harun, 2007). From a banking perspective, image has also been found to influence loyalty (Ayuni, Hussein \& Handrito, 2015). In the context of the hotel industry, study also has found that a favourable perceived image will be able to improve customer's loyalty (De Leaniz \& Del Bosque Rodríguez, 2016). Therefore, based on the results of these previous studies, this study proposed three hypotheses:

$\mathrm{H}_{1}$ : There is a positive and significants relationship between firm's communication and the corporate brand image of Islamic banking institutions. 
$\mathrm{H}_{2}$ : There is a positive and significant relationship between nonfirm's communication and the corporate brand image of Islamic banking institutions.

$\mathrm{H}_{3}: \quad$ There is a significant relationship between the corporate brand image of Islamic bank and loyalty.

The model in Figure 1 shows the link between the proposed construct:

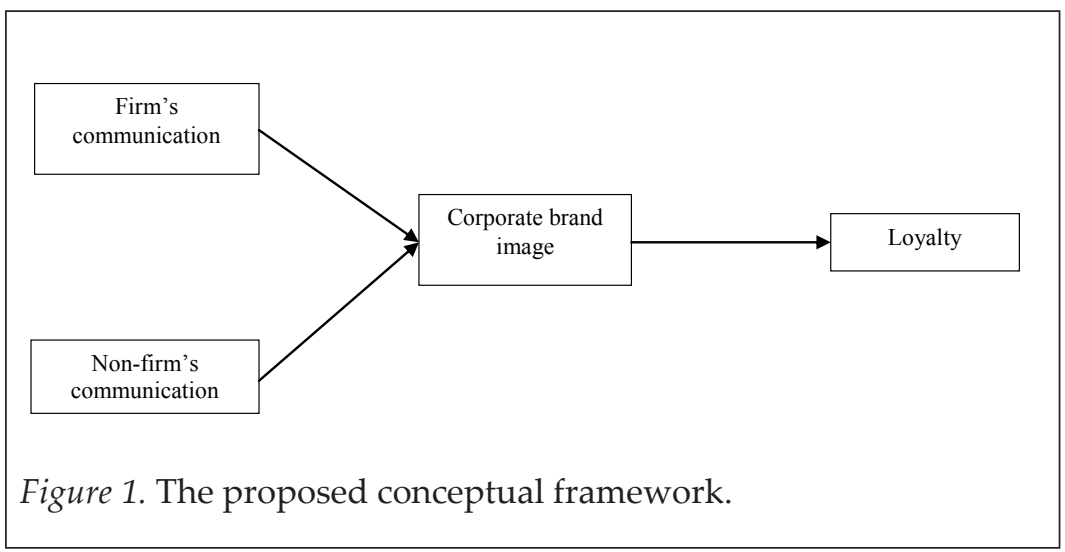

\section{Methodology}

The study utilised a purposive sampling technique to collect the data. In selecting the right respondents, two qualifying criteria were determined: (1) Must be an adult at the age of 18 and above, and (2) must own an Islamic banking account for at least six months. The duration of at least six months is required as it is considered an adequate length for customers to evaluate their experience with the bank (Dagger, Danaher, \& Gibbs, 2009) while adult customers are chosen with the assumption that they have the ability to make the decision on banking matters (Dusuki \& Abdullah, 2007). In the process of collecting data, a self-administered questionnaire was used. The questionnaires were distributed to the Human Resource Department of public and private companies and institutions to be passed on to the employees. Overall, the data collection process took one month to be completed.

From 250 questionnaires distributed, 202 questionnaires were received. However, 34 questionnaires were rejected because some of 
the respondents did not own the Islamic banking accounts while the rest of the other questionnaires were incomplete. Finally, only 168 questionnaires were considered valid which represent a response rate of 67.2 percent. Of the 168 respondents, 60.1 percent were female and 99.4 percent were Muslim. The majority of the respondents were between the aged of 31 to 40 and possess either a diploma or a bachelor's degree; 84.5 percent of them worked in the public sector and the majority of them received between RM2001 to RM5000.

There are four constructs under the study; they are firm's communication, non-firm's communication, corporate brand image and loyalty. The questionnaire used in this study was created based on the instrument developed and tested by Bravo et al. (2012), Lee (2004), and also Nguyen and Leblanc (2001). It was prepared in two languages, Malay and English, and assessed using a six-point Likert scale.

\section{Analysis and Result}

The Partial Least Square-Structural Equation Modeling (PLS-SEM) analysis was carried out using smart PLS3.0 software. At the first stage, the measurement model was tested to examine the validity and reliability of the measures. Then, the structural model was computed to test the hypothesised relationship. This was done through the bootstrapping method so that the loading and the path coefficients significant could be determined.

\section{Assessment of the Measurement Model}

Four reflective constructs were involved in this study which are firm communication, non-firm communication, corporate brand image and loyalty. Following the guideline by Hair, Hult, Ringle, and Sarstedt (2017), the analysis was conducted on the convergent validity which indicated the degree to which the items were measuring the same construct. The assessment was done on the factor loadings, composite reliability (CR) and average variance extracted (AVE) (Hair, Hult, Ringle, \& Sarstedt, 2014). As presented (Table 1 and Figure 2), the result shows that the loadings for all items range between 0.820 and 0.924 which are more than the cut-off value of 0.5 (Hair et al., 2014). The Composite Reliability on the other hand ranges between 0.925 and 0.945 , which is above the recommended value of 0.7 (Hair et al., 2014). This indicate that the measurement model possesses acceptable 
reliability. Lastly, the AVE which indicates the amount of variance represented by a single construct ranges between 0.755 and 0.817 , is also exceeding the value recommended by Hair et al. (2014) which is 0.5 . Thus, it can be concluded that the measurement model has convergent validity.

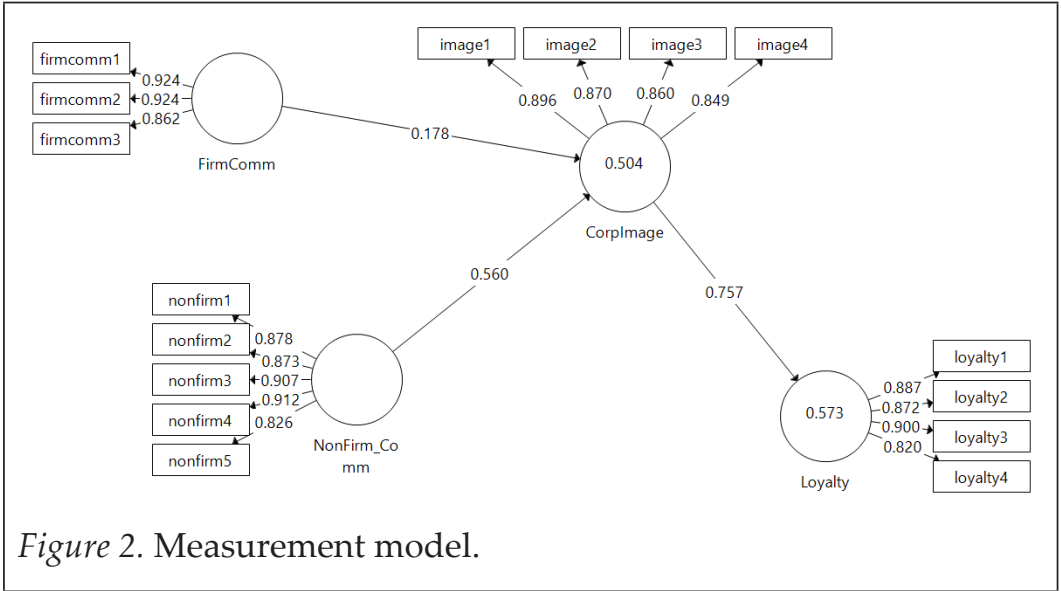

Table 1

Result of the Measurement Model

\begin{tabular}{llccc}
\hline Construct & \multicolumn{1}{c}{ Item } & Loadings & AVE & CR \\
\hline Firm communication & firmcomm1 & 0.924 & 0.817 & 0.930 \\
& firmcomm2 & 0.924 & & \\
& firmcomm3 & 0.862 & & \\
Non-firm communication & nonfirm1 & 0.878 & 0.774 & 0.945 \\
& nonfirm2 & 0.873 & & \\
& nonfirm3 & 0.907 & & \\
nonfirm4 & 0.912 & & \\
Corporate image & nonfirm5 & 0.826 & & \multirow{2}{*}{0.925} \\
& image1 & 0.896 & 0.755 & \\
& image2 & 0.870 & & \\
Loyalty & image3 & 0.860 & & \\
& image4 & 0.849 & & \multirow{2}{*}{0.926} \\
& loyalty1 & 0.887 & 0.757 & \\
& loyalty2 & 0.872 & & \\
& loyalty3 & 0.900 & & \\
& loyalty4 & 0.820 & & \\
\hline
\end{tabular}


Then, the assessment of discriminant validity was conducted using the Fornell and Larcker (1981) criterion as well as the heterotraitmonotrait ratio of correlation (HTMT) (Henseler, Ringle, \& Sarstedt, 2015). Table 2 shows that the square root of AVE is higher than the correlation of the construct, which provides evidence to establish the discriminant validity. This result is also supported by the finding of HTMT assessment in table 3 which shows that the discriminant validity is established with $\mathrm{HTMT}_{0.90}$. In summary, the measurement model demonstrates enough convergent and discriminant validity.

Table 2

Discriminant Validity of Constructs

\begin{tabular}{lcccc}
\hline & 1 & 2 & 3 & 4 \\
\hline 1. Firm commmunication & 0.904 & & & \\
2. Corporate image & 0.625 & 0.869 & & \\
3. Loyalty & 0.563 & 0.757 & 0.87 & \\
4. Non-firm Communication & 0.799 & 0.702 & 0.692 & 0.88 \\
\hline
\end{tabular}

Source: Fornell and Lacker (1981)

Table 3

Discriminant Validity of Constructs (HTMT)

\begin{tabular}{lcccc}
\hline & 1 & 2 & 3 & 4 \\
\hline 1. Firm commmunication & & & & \\
2. Corporate image & 0.699 & & & \\
3. Loyalty & 0.63 & 0.837 & & \\
4. Non-firm Communication & 0.88 & 0.771 & 0.758 & na \\
\hline
\end{tabular}

\section{Assessment of the Structural Model}

Tables 4 and 5 present the variance inflated factor (VIF), the coefficient of determination (R square), the predictive relevance (Q square) and the effect size $\left(f^{2}\right)$. The VIF values show that the collinearity issue does not exist as both VIF for the firm and non-firm communication constructs are less than the threshold value, which is 5 (Hair et al. 2017). This indicates that the constructs are significantly different from one another. In a similar vein, firm and non-firm communication explain 50.4 percent of the variance in corporate brand image while the image 
explains 57.3 percent of the variance in loyalty. In addition to that, the result also shows that non-firm communication has a large effect size on the corporate brand image $(\mathfrak{f} 2=0.229)$ while firm communication has a small effect on image ( $f 2=0.023)$. Lastly, the image is found to have a substantial effect on loyalty $(\mathrm{f} 2=1.340)$. Then, the predictive relevance of the exogenous variables on endogenous variables was assessed using blindfolding. The blindfolding assessment result shows that the exogenous variables have a predictive relevance over the endogenous variable as the values of $\mathrm{Q}^{2}$ for all predictors are more than 0 (Hair et al., 2014; Stone, 1974).

Table 4

Lateral Collinearity Assessment

\begin{tabular}{lcc}
\hline \multicolumn{1}{c}{ Construct } & Image (VIF) & Loyalty (VIF) \\
\hline Firm Communication & 2.765 & \\
Non-firm Communication & 2.765 & 1.000 \\
Image & & \\
Loyalty & & \\
\hline
\end{tabular}

Next, using a bootstrapping technique of a 5000 resample, the structural model was evaluated to test the hypotheses. The variance explained for the model is shown in table 5. The $t$-value shows that all three hypotheses were supported. Firm communication was significantly related to the corporate brand image $(\beta=0.178, p<0.05)$ and non-firm communication was positively related to the corporate brand image $(\beta=0.560, p<0.05)$. On the other hand, the corporate brand image was also significantly related to loyalty $(\beta=0.757, p<0.05)$.

Table 5

Hypothesis Testing

\begin{tabular}{clccccccc}
\hline & & Std & Std & $\mathrm{t}-$ & & & & \\
Hypothesis & \multicolumn{1}{c}{ Relationship } & Beta & Error & value & Decision & $\mathrm{R}^{2}$ & $\mathrm{f}^{2}$ & $\mathrm{Q}^{2}$ \\
\hline $\mathrm{H}_{1}$ & Firm Comm -> Image & 0.178 & 0.097 & 1.825 & Supported & 0.504 & 0.023 & 0.335 \\
$\mathrm{H}_{2}$ & Non-firm -> Image & 0.560 & 0.085 & 6.601 & Supported & & 0.229 & \\
$\mathrm{H}_{3}$ & Image -> Loyalty & 0.757 & 0.036 & 20.915 & Supported & 0.573 & 1.340 & 0.381 \\
\hline
\end{tabular}


IJMS 27(1), 49-72 (2020)

\section{Discussion and Conclusion}

Building and maintaining favourable corporate image is crucial as it is said to be among the main reasons that influence sales and selection (Hee Youn \& Ji-Hwan, 2013; Hemsley-brown, Melewar, Nguyen, \& Wilson, 2016). Not only that, the image is also able to drive the brand equity (Van Rekom, Jacobs, \& Verlegh, 2006), to influence company's position in the mind of consumers (Aaker, 1991; Biel, 1993), and is difficult to be copied by competitors (Sondoh Jr et al., 2007). In view of this importance, this study has investigated the role of corporate communication in building images and the effects of the image on the customer's loyalty. With this in mind, a model has been proposed and validated. Findings of the statistical analysis indicate that both firm and non-firm communication plays a role in influencing the corporate brand image of Islamic bank, especially in Malaysia. Among the two, the beta value, however, shows that non-firm communication plays a bigger role in influencing image compared to the firm communication. This is similar with the findings of several previous studies in the conventional financial institutions which reveal that both corporate communication tools have an effect towards image (Bravo, Montaner, \& Pina, 2010), and in the case of severe instances where the word-ofmouth spreads widely or becomes viral, the non-firm communication thus will be more impactful than the earlier (Berry, 2000). In addition, the corporate brand image also was proven to significantly affect customer's loyalty towards Islamic bank, indicating that the higher the customers perceive the image of a bank, the higher the probability of the customers to retain their loyalty to the bank. This is supported by other studies in various fields that show the existence of a significant relationship between image and loyalty (Ayuni et al., 2015; Da Silva \& Syed Alwi, 2006; Sondoh Jr et al., 2007).

\section{Implications}

Based on the findings presented in this study, several recommendations and implications can be considered by an Islamic bank in order to enhance its corporate brand image and at the same time improve its customers' loyalty. First, the result of the analysis reveals that firm communication plays a positive and significant role in influencing the image of Islamic bank, although the effect is low. This low effect may be attributed to the Islamic bank's ineffective promotional efforts found by Loo (2010) previously. In general, banking customers are 
said to pay less attention to the bank's publicity materials such as annual report, brochures and pamphlets (Yeo \& Youssef, 2010). In view of this, it is therefore essential for the Islamic bank to ensure that effective communications are being delivered to customers and potential customers. Not only that, the messages communicated by the bank through various medium such as advertising, personal selling, public relation, and direct marketing should reflect the philosophy and personality of the company and coherent with the company's culture and belief to avoid contradicting experience during customers' encounter with the product or service (Balmer \& Greyser, 2003; Suhartanto, 2019). In addition, in today's era of technological advancement, Islamic banks should also consider the utilisation of lower cost online options such as blogs or weblogs that allow users to comment and social media sites such as Facebook and Twitter (Bruhn, Schoenmueller, \& Schäfer, 2012) that permit a two-way communication. This is due to the findings of previous studies that proved the ability of these social networking channels in constructing the corporate brand image (Bruhn et al., 2012; Gilpin, 2010).

Second, the significant relationship that exists between non-firm communication and corporate brand image shows the importance of Islamic bank management in managing its non-firm communication such as word-of-mouth, publicity and word-of-mouse. Although non-firm communication is said to reach fewer people than the firm communication, the impact might have been bolder if it gets a wider attention and publicity (Berry, 2000), thus affecting not only the corporate brand image but also the brand equity. In the time of widespread usage of online media today, where word-of-mouse and negative online product review can become viral in a short time, its effect towards image therefore can be detrimental (Bambauer-Sachse $\&$ Mangold, 2011). Hence, to monitor and manage the effect of nonfirm communication, the Islamic banking managers are encouraged to examine the bank's brand health by monitoring the customers' feedback surveys, findings of commercial survey and also the customers' comments in the social media sites and forums (Sweeney, Soutar, \& Mazzarol, 2014). In addition, banks can engage and educate customers and potential customers to build their expertise on the Islamic banking products which in the long run can lead them to spread positive messages (Sweeney et al., 2014).

Finally, the significant relationship between corporate brand image and loyalty also stressed on the findings of previous studies on the 
importance of developing favourable corporate image to encourage repeat patronage. Therefore, in the effort of increasing retention, it is highly critical for Islamic banking managers to ensure that not only the firm and non-firm communications are favourable, but also other factors affecting the corporate brand image such as the contact personnel, the service accessibility and the products and services offered are all properly managed.

\section{Limitations}

There are several constraints that should be considered in generalising this study. First, the study has been aimed towards Islamic banking customers in certain regions in Malaysia only, which may limit its ability to be interpreted towards other Islamic banking customers in the world. Second, despite the fact that Islamic banking customers comprise Muslims and non-Muslims, this study was only able to get responses from a very small percentage of non-Muslims which may not represent the views of other non-Muslim customers. Third, the data collection was conducted using non-probability purposive sampling technique which lack of randomness and representativeness and this may cause limited generalisability of the findings to the whole population.

\section{Conclusion}

The study reveals that firm and non-firm communications has a significant relationship with the image, while image also play a crucial role in influencing loyalty. As an improvement to this, future studies may consider to test the relationship between firm and nonfirm communication to the specific dimension of image such as the functional and emotional brand images. In addition, future study may also consider to test the role of corporate brand image in mediating the relationship between corporate communication and loyalty.

\section{References}

Aaker, D. A., Batra, R., \& Myers, J. G. (1982). Advertising management. Englewood Cliffs, NJ: Prentice-Hall.

Aaker, David A. (1991). Managing brand equity: Capitalizing on a value of a brand name. New York: The Free Press. 
Ab Hamid, S. N., \& Wan Jusoh, W. J. (2016). Corporate image of zakat institutions in Malaysia. Malaysian Journal of Society and Space, 12(2), 47-57.

Ahmad, K., Rustam, G. A., \& Dent, M. M. (2011). Brand preference in Islamic banking. Journal of Islamic Marketing, 2(1), 74-82.

Ahmed, M., Ali, S. A., Jan, M. T., \& Hassan, A. (2019). Development of Islamic banks' brand personality (IBBP) model: A conceptual study in Malaysia. Journal of Islamic Marketing, 11(3), 621-642. Doi: 10.1108/JIMA-11-2018-0210

Al-Tamimi, H. A. H., Lafi, A. S., \& Uddin, M. H. (2009). Bank image in the UAE: Comparing Islamic and conventional Banks. Journal of Financial Services Marketing, 14(3), 232-244.

Ansary, A., \& Nik Hashim, N. M. H. (2018). Brand image and equity: The mediating role of brand equity drivers and moderating effects of product type and word of mouth. Review of Managerial Science, 12(4), 969-1002. Doi: 10.1007/s11846-017-0235-2

Awan, H. M., Hayat, S., \& Faiz, R. (2018). Antecedents and consequences of corporate image: Conventional and Islamic banks. Journal of Business Management, 58(4), 418-432. Doi: 10.1590/S0034-759020180407

Ayuni, R. F., Hussein, A. S., \& Handrito, R. (2015). Role of religion motives and brand image towards consumer satisfaction and consumer loyalty of Islamic banking. The International Journal of Accounting and Business Society, 23(2), 55-68.

Bălășescu, S. (2019). Methods of assessing the image of cosmetics industry retailers. Series $V$ - Economic Sciences, 12(61)(1), 15-22. Doi: $10.31926 /$ but.es.2019.12.61.1.2

Balmer, J. M. T., \& Gray, E. R. (2000). Corporate identity and corporate communications: Creating a competitive advantage. Industrial and Commercial Training, 32(7), 256-262. Doi: 10.1108/ EUM0000000007299

Balmer, J. M. T., \& Greyser, S. A. (2003). Revealing the corporation: Perspectives on identity, image, reputation, corporate branding, and corporate-level marketing. London: Routledge: Taylor \& Francis Group.

Bambauer-Sachse, S., \& Mangold, S. (2011). Brand equity dilution through negative online word-of-mouth communication. Journal of Retailing and Consumer Services, 18(1), 38-45. Doi: 10.1016/j.jretconser.2010.09.003

Barich, H., \& Kotler, P. (1991). A framework for marketing image management. Sloan Management Review, 32(2), 94-104. 
Belwal, R., \& Al Maqbali, A. (2019). A study of customers' perception of Islamic banking in Oman. Journal of Islamic Marketing, 10(1), 150-167. Doi: 10.1108/JIMA-02-2016-0008

Berndt, A., \& Hollebeek, L. D. (2019). Brand image and reputation development in higher education institutions. In Strategic Brand Management in Higher Education. Routledge.

Berry, L. L. (2000). Cultivating service brand equity. Journal of the Academy of Marketing Science, 28(1), 128-137. Doi: 10.1177/0092070300281012

Biel, A. L. (1993). Converting image into equity. In Brand Equity $\mathcal{E}$ Advertising: Advertising's role in building strong brands (pp. 6782). New Jersey: Lawrence Erlbaum Associates.

Blombäck, A., \& Axelsson, B. (2007). The role of corporate brand image in the selection of new subcontractors. Journal of Business \& Industrial Marketing, 22(6), 418-430. Doi: $10.1108 / 08858620710780181$

Bravo, R., Montaner, T., \& Pina, J. M. (2010). Corporate brand image in retail banking: Development and validation of a scale. The Service Industries Journal, 30(8), 1199-1218. Doi: 10.1080/02642060802311260

Bravo, R., Montaner, T., \& Pina, J. M. (2012). Corporate brand image of financial institutions: A consumer approach. Journal of Product \& Brand Management, 4(21), 232-245. Doi: $10.1108 / 10610421211246649$

Bruhn, M., Schoenmueller, V., \& Schäfer, D. B. (2012). Are social media replacing traditional media in terms of brand equity creation? Management Research Review, 35(9), 770-790. Doi: 10.1108/01409171211255948

Chaouch, N. (2017). An exploratory study of Tunisian customers' awareness and perception of Islamic banks. International Journal of Islamic Economics and Finance Studies, 3(2), 7-32.

Chen, C.-C., Chen, P.-K., \& Huang, C.-E. (2012). Brands and consumer behavior. Social Behavior \& Personality: An International Journal, 40(1), 105-114. Doi: 10.2224/sbp.2012.40.1.105

Chong, B. S., \& Liu, M. H. (2009). Islamic banking: Interest-free or interest-based? Pacific Basin Finance Journal, 17(1), 125-144. Doi: 10.1016/j.pacfin.2007.12.003

Chung, K., Yu, J.-E., Kim, W., \& Shin, J.-I. (2016). The antecedent and consequences of brand image in a low-priced cosmetic brand of South Korea: The moderating effect of gender. International Journal of $U$ - and e- Service, Science and Technology, 9(2), 175-184.

Cornelissen, J. (2000). Corporate image: An audience centred model. Corporate Communications: An International Journal, 5(2), 119-125. 
Da Silva, R. V., \& Syed Alwi, S. F. (2006). Cognitive, affective attributes and conative, behavioural responses in retail corporate branding. Journal of Product \& Brand Management, 15(5), 293305. Doi: $10.1108 / 10610420610685703$

Da Silva, R. V., \& Syed Alwi, S. F. (2008). Online brand attributes and online corporate brand images. European Journal of Marketing, 42(9/10), 1039-1058. Doi: 10.1108/03090560810891136

Dagger, T. S., Danaher, P. J., \& Gibbs, B. J. (2009). How often versus how long: The interplay of contact frequency and relationship duration in customer-reported service relationship strength. Journal of Service Research, 11(4), 371-388.

de Chernatony, L., \& Riley, F. D. (1998). Defining a "Brand": Beyond the literature with experts' interpretations. Journal of Marketing Management, 14(5), 417-443. Doi: 10.1362/026725798784867798

De Leaniz, P. M. G., \& Del Bosque Rodríguez, I. R. (2016). Corporate image and reputation as drivers of customer loyalty. Corporate Reputation Review, 19(2), 166-178. Doi: 10.1057/crr.2016.2

Dichter, E. (1985). What is in an image? Journal of Consumer Research, $13,455-472$.

Dick, A. S., \& Basu, K. (1994). Customer loyalty: Toward an integrated conceptual framework. Journal of the Academy of Marketing Science, 22(2), 99-113. Doi: 10.1177/0092070394222001

Dowling, G. R. (1986). Managing your corporate images. Industrial Marketing Management, 15, 109-115.

Dowling, G. R. (1993). Developing your company image into a corporate asset. Long Range Planning, 26(2), 101-109. Doi: 10.1016/0024-6301(93)90141-2

Dusuki, A. W., \& Abdullah, N. I. (2007). Why do Malaysian customers patronise Islamic banks? International Journal of Bank Marketing, 25(3), 142-160. Doi: 10.1108/02652320710739850

Esmaeilpour, F. (2015). The role of functional and symbolic brand associations on brand loyalty: A study on luxury brands. Journal of Fashion Marketing and Management, 19(4), 467-484. Doi: 10.1108/MRR-09-2015-0216

Farida, N., \& Ardyan, E. (2018). The driving of customer loyalty: Relational approach, perceived value and corporate image. International Journal of Business and Society, 19(1), 15-26.

Fornell, C., \& Larcker, D. F. (1981). Evaluating structural equation models with unobservable variables and measurement error. Journal of Marketing Research, 18(1), 39-50. 
Gaither, T. K., \& Al-Kandari, A. J. (2014). The cultural-economic model and public relations in the Middle East: An examination of the Islamic banking system in Kuwait. Public Relations Review, 40(1), 33-41. Doi: 10.1016/j.pubrev.2013.11.003

Gilpin, D. (2010). Organizational image construction in a fragmented online media environment. Journal of Public Relations Research, 22(3), 265-287. Doi: 10.1080/10627261003614393

Giovanis, A., \& Tsoukatos, E. (2017). An integrated model of the effects of service evaluation, corporate image, and switching barriers on customer loyalty. Journal of Transnational Management, 22(1), 4-24. Doi: 10.1080/15475778.2017.1274612

Hair, J. F., Hult, G. T. M., Ringle, C. M., \& Sarstedt, M. (2014). A primer on partial least squares structural equation modeling (PLS-SEM). Thousand Oaks: Sage.

Hair, J. F., Hult, G. T. M., Ringle, C. M., \& Sarstedt, M. (2017). A primer on partial least squares structural equation modeling (PLS-SEM) (2nd ed.). Los Angeles: Sage Publications.

Haniffa, R., \& Hudaib, M. (2007). Exploring the ethical identity of Islamic banks via communication in annual reports. Journal of Business Ethics, 76(1), 97-116. Doi: 10.1007/s10551-006-9272-5

Hee Youn, K., \& Ji-Hwan, Y. (2013). Examining national tourism brand image: Content analysis of Lonely Planet Korea. Tourism Review of AIEST - International Association of Scientific Experts in Tourism, 68(2), 56-71. Doi: 10.1108/TR-10-2012-0016

Hemsley-brown, J., Melewar, T. C., Nguyen, B., \& Wilson, E. J. (2016). Exploring brand identity, meaning, image, and reputation (BIMIR) in higher education: A special section. Journal of Business Research, 69(8), 3019-3022. Doi: 10.1016/j.jbusres.2016.01.016

Henseler, J., Ringle, C. M., \& Sarstedt, M. (2015). A new criterion for assessing discriminant validity in variance-based structural equation modeling. Journal of the Academy of Marketing Science, 43(1), 115-135.

Hosany, S., Ekinci, Y., \& Uysal, M. (2006). Destination image and destination personality: An application of branding theories to tourism places. Journal of Business Research, 59(5), 638-642. Doi: 10.1016/j.jbusres.2006.01.001

Hung, C.-H. (2008). The effect of brand image on public relations perceptions and customer loyalty. International Journal of Management, 25(2), 237-246.

IFSB. (2019). Islamic Financial Services Industry Stability Report 2019. Kuala Lumpur. Retrieved from file://C:/Users/user/Downloads/Islamic Financial Services Industry Stability Report 2019_En.pdf 
Johnson, M., \& Zinkhan, G. M. (1990). Defining and measuring company image. In Proceedings of the Thirteenth Annual Conference of the Academy of Marketing Science XIII (pp. 346-350). New Orleans, LA. Doi: 10.1007/978-3-319-13254-9

Juhari, A. S., Bhatti, M. A., \& Piaralal, S. K. (2016). Service quality and customer loyalty in Malaysian Islamic insurance sector exploring the mediating effects of customer satisfaction. International Journal of Academic Research in Business and Social Sciences, 6(3), 2222-6990. Doi: 10.6007/IJARBSS/v6-i3/2030

Kaakeh, A., Hassan, M. K., \& van Hemmen Almazor, S. F. (2018). Attitude of Muslim minority in Spain towards Islamic finance. International Journal of Islamic and Middle Eastern Finance and Management, 11(2), 213-230. Doi: 10.1108/IMEFM-11-2017-0306

Khan, F. (2010). How "Islamic" is Islamic Banking? Journal of Economic Behavior and Organization, 76(3), 805-820. Doi: 10.1016/j. jebo.2010.09.015

Klein, K., Völckner, F., Bruno, H. A., Sattler, H., \& Bruno, P. (2019). Brand positioning based on brand image-country image fit. Marketing Science, 38(3), 516-538. Doi: 10.1287/mksc.2019.1151

Konuk, F. A. (2018). The role of store image, perceived quality, trust and perceived value in predicting consumers' purchase intentions towards organic private label food. Journal of Retailing and Consumer Services, 43(April), 304-310. Doi: 10.1016/j. jretconser.2018.04.011

Kuuru, T.-K., \& Tuominen, P. (2016). Creating a conceptual framework for corporate brand positioning. In Business Challenges in the Changing Economic Landscape (Vol. 2, pp. 177-195). Cham: Springer. Doi: 10.1007/978-3-319-22593-7_13

Lahap, J., Ramli, N. S., Radzi, S. M., Said, N. M., \& Zain, R. A. (2016). Brand image towards customer's satisfaction: A focus on the Malaysian hotel sector. Procedia - Social and Behavioral Sciences, 00, 11-15. Doi: 10.13140/RG.2.1.4320.2006

Lee, B. K. (2004). Corporate image examined in a Chinese-based context: A study of a young educated public in Hong Kong. Journal of Public Relations Research, 16(1), 1-34.

Loo, M. (2010). Attitudes and perceptions towards Islamic banking among Muslims and Non-Muslims in Malaysia: Implications for marketing to baby boomers and X-Generation. International Journal of Arts and Sciences, 3(13), 453-485.

Mazzei, A. (2014).A multidisciplinary approach for a new understanding of corporate communication. Corporate Communications: An 
IJMS 27(1), 49-72 (2020)

International Journal, 19(2), 216-230. Doi: 10.1108/CCIJ-12-20110073

Michaelidou, N., Micevski, M., \& Cadogan, J. W. (2015). An evaluation of nonprofit brand image: Towards a better conceptualization and measurement. Journal of Business Research, 68(8), 1657-1666. Doi: 10.1016/j.jbusres.2015.03.024

Mohamad, J., \& Majid, M. F. C. (2016). A study on the customer's acceptance towards Islamic banking products among nonMuslim in dual banking system. International Journal of Management Studies, 23(1), 1-11.

Nguyen, B., Yu, X., Melewar, T. C., \& Hemsley-brown, J. (2016). Brand ambidexterity and commitment in higher education: An exploratory study. Journal of Business Research, 69(8), 3105-3112. Doi: 10.1016/j.jbusres.2016.01.026

Nguyen, N., \& Leblanc, G. (2001). Corporate image and corporate reputation in customers' retention decisions in services. Journal of Retailing and Consumer Services, 8(4), 227-236.

O'Cass, A., \& Grace, D. (2003). An exploratory perspective of service brand associations. Journal of Services Marketing, 17(5), 452-475. Doi: 10.1108/08876040310486267

Osman, I., Ali, H., Mokhtar, I., Setapa, F., \& Abd Malek, A. B. (2016). Corporate image and brand identification of Islamic banks: The perspective of customers. In Proceedings of the 1st AAGBS International Conference on Business Management 2014 (AiCoBM 2014) (pp. 297-308). Springer Singapore. Doi: 10.1007/978-981287-426-9

Osman, I., Syed Alwi, S. F., Mokhtar, I., Ali, H., Setapa, F., Rahim, A. R. A., \& Muda, R. (2015). Integrating institutional theory in determining corporate image of Islamic banks. In Procedia - Social and Behavioral Sciences (Vol. 211, pp. 560-567). Elsevier B.V. Doi: 10.1016/j.sbspro.2015.11.074

Palazzo, M., Foroudi, P., Kitchen, P. J., \& Siano, A. (2020). Developing corporate communications: An exploratory study. Qualitative Market Research: An International Journal. Doi: 10.1108/QMR-122017-0185

Prayag, G., Hosany, S., Muskat, B., \& Del Chiappa, G. (2017). Understanding the relationships between tourists' emotional experiences, perceived overall image, satisfaction, and intention to recommend. Journal of Travel Research, 56(1), 41-54. Doi: $10.1177 / 0047287515620567$ 
Sadek, H., Redding, P., \& Tantawi, P. (2015). Investigating the major marketing communication tools and their impact on building bank brand equity in the Egyptian context: A customer perspective. Journal of Business \& Retail Management Research, 10(1), 40. Retrieved from http://search.ebscohost.com/login.asp

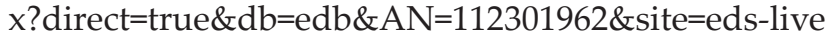

Saleh, M. A., Quazi, A., Keating, B., \& Gaur, S. S. (2017). Quality and image of banking services: A comparative study of conventional and Islamic banks. International Journal of Bank Marketing, 35(6), 878-902. Doi: 10.1108/02652323199400002

Sallam, M. A. (2016). An investigation of corporate image effect on WOM: The role of customer satisfaction and trust. International Journal of Business Administration, 7(3), 27-35. Doi: 10.5430/ijba. v7n3p27

Shabbir, M. Q., Khan, A. A., \& Khan, S. R. (2017). Brand loyalty, brand image and brand equity: The mediating role of brand awareness. International Journal of Innovation and Applied Studies, 19(2), 416-423. Retrieved from http://www.ijias.issr-journals. org/

Sondoh Jr, S. L., Wan Omar, M., Abdul Wahid, N., Ismail, I., \& Harun, A. (2007). The effect of brand image on overall satisfaction and loyalty intention in the context of color cosmetic. Asian Academy of Management Journal, 12(1), 83-107.

Souiden, N., \& Rani, M. (2015). Consumer attitudes and purchase intentions toward Islamic banks: The influence of religiosity. International Journal of Bank Marketing, 33(2), 143-161. Doi: 10.1108/IJBM-10-2013-0115

Stone, M. (1974). Cross-validatory choice and assessment of statistical predictions. Journal of the Royal Statistical Society. Series B (Methodological), 36(2), 111-147.

Suhartanto, D. (2019). Predicting behavioural intention toward Islamic bank: A multi-group analysis approach. Journal of Islamic Marketing, 10(4), 1091-1103. Doi: 10.1108/JIMA-02-20180041

Sweeney, J., Soutar, G., \& Mazzarol, T. (2014). Factors enhancing word-of-mouth influence: Positive and negative service-related messages. European Journal of Marketing, 48(1/2), 336-359. Doi: 10.1108/EJM-06-2012-0336

Tran, M. A., Nguyen, B., Melewar, T. C., \& Bodoh, J. (2015). Exploring the corporate image formation process. Qualitative Market Research: An International Journal, 18(1), 86-114. 
IJMS 27(1), 49-72 (2020)

Van Rekom, J., Jacobs, G., \& Verlegh, P. W. J. (2006). Measuring and managing the essence of a brand personality. Marketing Letters, 17(3), 181-192. Doi: 10.1007/s11002-006-5362-5

Van Riel, C. B. M. (1995). Principles of corporate communication. London: Prentice Hall.

Widyastutir, S., \& Said, M. (2017). Consumer consideration in purchase decision of SPECS sports shoes product through brand image, product design and price perception. International Journal of Supply Chain Management, 6(4), 199-207.

Yeo, R. K., \& Youssef, M. A. (2010). Communicating corporate image into existence: The case of the Saudi banking industry. Corporate Communication An International Journal, 15(3), 263-280. Doi: 10.1108/13563281011068122 